\title{
Ecos do populismo do leste europeu em colônia de imigrante
}

\author{
Maria Luiza Andreazza*
}

Batatas em um saco constituem um saco de batatas.

Karl Marx

Uma parcela expressiva dos estudos que se ocupam com os movimentos dos trabalhadores na Primeira República associa os imigrantes à divulgação de ideários que questionavam os fundamentos das relações capitalistas. Em tais pesquisas, ao relacionarem italianos à difusão do anarquismo no Brasil, os pesquisadores sequer cogitam sugerir que essa teoria política expressasse traço de italianidade. Ao contrário, o que se enfatiza é que a identidade produzida pelos movimentos sociais das primeiras décadas do século XX foi de outra natureza. Ângela de Castro Gomes, por exemplo, afirma que essa foi a época em que o operariado brasileiro ainda se organizava como categoria e, assim, na perspectiva dos processos de coesão social, os acontecimentos que ocorreram aí consistiram em experiências bastante substantivas para engendrar a identidade social do trabalhador brasileiro. ${ }^{1}$ Aceitando-se que os campos identitários se organizam por mecanismos de inclusão e de

"Professora associada da Universidade Federal do Paraná (UFPR) e pesquisadora do Conselho Nacional de Desenvolvimento Científico e Tecnológico (CNPQ). Parte significativa desse texto foi apresentado no VI CEISAL (Toulouse - 2010). mluiza@ufpr.br

${ }^{1}$ GOMES, Ângela Maria de Castro. A invenção do trabalhismo. 3. ed. Rio de Janeiro: Editora FGV, 2005. p. 30. 
exclusão, vale observar que tais mecanismos, no mais das vezes, são acionados por oposições muito simples.

No caso do mundo do trabalho brasileiro do começo do século XX, por exemplo, situar-se entre os que vendiam sua força de trabalho definia-se como passe para assumir a identidade operária. Afinal, a contrastividade ${ }^{2}$ entre as posições sociais de patrões e operários era suficiente para demarcar os campos de alteridade. Desse ponto de vista, e acrescentando o que foi dito acima, pode-se indicar que nas primeiras décadas do século XX o universo do trabalho brasileiro contava com mão de obra estrangeira de inúmeras origens étnicas. Esses estrangeiros, ao lado dos "nacionais", integraram grupos que se envolveram com inúmeros movimentos sociais, acirrada militância com o propósito, no entanto, de alcançar e fortalecer garantias a uma classe e não a uma etnia.

Efetivamente, fatores de natureza politica favoreceram a associação dos imigrantes-citadinos-operários aos movimentos sociais do período aqui estudado. Sabe-se que, herdeiros de concepções político-filosóficas de cunho evolucionista, os intelectuais e militares que fundaram a República defendiam a tese do progresso ordeiro. ${ }^{3}$ Por isso, toda a Primeira República buscou implementar uma ordem política no interior da qual "o povo seria uma agremiação de cidadãos unidos por laços de disciplina”. ${ }^{4}$ Aos transgressores desse ideal, o Estado reservava medidas repressivas que privilegiavam o encarceramento dos que promoviam a "desordem pública" devido à bebida, arruaças e congêneres. Por essa justificativa também eram presos imigrantes considerados "desordeiros" por difundirem ideias anarquistas, socialistas, sindicalistas, grevistas,

\footnotetext{
${ }^{2}$ OLIVEIRA, Roberto C. Identidade, etnia e estrutura social. São Paulo: Livraria Pioneira Editora, 1976; BARTH, Frederick. Grupos étnicos e suas fronteiras. In: POUTIGNAC, P. Streiff-Fenard,J. Teorias da etnicidade. Seguido de grupos étnicos e suas fronteiras de Fredrik Barth, São Paulo: UNESP, 1998.
}

${ }^{3}$ PATTO, Maria Helena Souza. Estado, ciência e politica na Primeira República: a desqualificação dos pobres. Estudos Avançados. 1999, v. 13, n. 35, p. $167-$ 198. < HTTP://wwW.SCIELO.BR/PDF/EA/v13N35/v13N35A17.PDF) ACESSADO EM 12 DE OUTUBRO DE 2010.

${ }^{4}$ GOMES, Ângela Maria de Castro. op. cit, p. 44

10 Revista de História Regional 16(1): 9-36, Verão, 2011 
propagandistas antirreligiosos, antivoto, feministas, etc. ${ }^{5}$ Tendo em vista apenas essa última categoria de desordens, é possivel levantar duas questões. A primeira é a de que, na terra de origem, esses "desordeiros" estiveram em contato ou alinhados a algum dos inúmeros movimentos sociais que vicejavam na Europa Oitocentista - grande parte deles, como se sabe, preocupada em minimizar os efeitos nefastos do capitalismo quando não propriamente em extingui-lo; a outra parte desses movimentos, herdeira do Iluminismo, dedicava-se a abolir o obscurantismo clerical e a menoridade da mulher. A segunda questão, que para fins deste estudo vale a pena realçar, é a de que tais "desordens" estariam imbricadas tão somente a pautas próprias - pertinentes e/ ou decorrentes - à Europa Ocidental urbana.

É certo que não foi intenção dos pesquisadores que se ocuparam com a classe operária isolar os imigrantes-citadinos por nacionalidade para estabelecer relações entre origem nacional e ativismo politico. No entanto, para a argumentação que se segue é fundamental sublinhar a tendência dos estudos de relacionarem os imigrantes fixados nas cidades com as dinâmicas modernizantes que ocorreram nos espaços urbanos. Assim, mesmo situados em posição desfavorável na escala social, e inclusive por esse motivo, eles deteriam consciência politica e, portanto, não se furtaram a contestar e a negociar suas posições no contexto em que estavam inseridos.

Contrariamente, é mais comum as investigações que focalizam o comportamento social dos imigrantes que se dirigiram às áreas rurais destacarem o empenho dos colonos na reconstrução de suas fronteiras étnicas, de seus traços identitários com base nos códigos de sociabilidades ancestrais. Salvo raras exceções, é enorme o silêncio historiográfico quanto à reorganização sociocultural dos colonos fixados

\footnotetext{
${ }^{5}$ PATTO, Maria Helena Souza. Estado, ciência e política na Primeira República: a desqualificação dos pobres. Estudos Avançados. 1999, v. 13, n. 35, p. 167-198; PINHEIRO, Paulo Sérgio. O proletariado industrial na Primeira República. In: FAUSTO, Boris (coord.) História Geral da Civilização Brasileira: O Brasil Republicano - Sociedade e Instituições. Tomo. III - v. 2, p. 135-178. Rio de Janeiro: Difel, 1977.
} 
nas áreas rurais contarem com elementos provenientes de alguma das correntes ideológicas disseminadas na Europa Oitocentista. Essa aparente despolitização dos imigrantes-colonos indicaria que, em suas recriações culturais, eles não se valeram de estratégias que pudessem beneficiá-los como integrantes de uma categoria social cuja existência transcendia os limites de suas comunidades. Mesmo quando os estudos indicam suas demandas junto às autoridades governamentais ou consulares, tais demandas são frequentemente explicadas como decorrentes da preocupação em manter seus lotes e escoar o excedente da produção, em nada sugerindo a presença de um sentimento coletivo que extrapolasse o bem da família, ou até mesmo individual.

De fato, boa parte dos estudos que analisam as comunidades rurais imigrantes evidencia a centralidade da vivência familiar na produção e manutenção dos signos étnicos ali presentes. Nesse sentido, sublinham a força das instituições religiosas e associativas, a endogamia dos comportamentos matrimoniais e compadrescos na produção das fronteiras étnicas, bem como buscam verificar os efeitos do tempo na transmissão geracional do campo costumeiro. Essa historiografia logrou identificar que os efeitos sociais da exteriorização dos atributos étnicos, dentre os quais a manutenção do idioma e o apreço à terra de origem, acabaram por tornar os colonos-imigrantes problema de Estado, gerando as politicas nacionalistas iniciadas nos anos 1920. Nesse caso, e diferentemente do que ocorria com os imigrante-citadinos, as politicas repressivas decorreram do fato étnico.

Muito embora sumarize, talvez demais, o teor de boa parte da produção dedicada aos imigrantes, o quadro montado até aqui permite encaminhar as seguintes perguntas: será que o contingente de imigrantes estabelecidos nas colônias do Sul do Brasil veio desprovido da consciência política manifestada pelos que se fixaram nas cidades? Será que os termos da relação coronelismo-enxada-voto, tão marcantes na política brasileira, tal como um virus, atingiram os imigrantes-colonos reduzindo-os à passividade? Será que os imigrantes-colonos seriam, tal como os camponeses do 18

12 Revista de História Regional 16(1): 9-36, Verão, 2011 
Brumário, excrescências feudais incompetentes para efetiva ação política?

O estudo de caso que se segue evidencia o contrário. Ao menos no que se refere ao comportamento dos pioneiros de um assentamento de ucranianos no sul do estado do $\mathrm{Pa}-$ raná, estabelecido em 1895 sob o nome de Colônia Antonio Olyntho.

Foi de ti, mujique, foi de ti que tudo procedeu - nobres, padres, sábios, czares, todos são antigos mujiques. Vês?

Compreendes?

Aprende a viver de forma a que te não batam mais.

Maximo Gorki

A grande maioria dos ucranianos ${ }^{6}$ que se dirigiu para o Brasil veio da Galícia - à época, a maior província do império austro-húngaro, situada a noroeste desses domínios. Ali, $80 \%$ da população se dividia entre poloneses e rutenos, porém, esses últimos se concentravam na porção oriental da provincia. A população restante dividia-se majoritariamente entre judeus e alemães. ${ }^{7}$

A posição sociopolítica dos ucranianos inspirava os lamentos de nacionalistas, como Iwan Frankó, que escreveu: "Meu povo sofredor e mutilado, igual a um lazarento no monturo pelo desdém dos homens ultrajado!"8 Esse poeta

\footnotetext{
${ }^{6}$ A designação regional que recebiam no momento da Grande Migração era de rutenos; em sua própria língua, chamavam-se rusyny. Por volta do final do século XIX, os rutenos galicianos e bucovinos passaram a favorecer a adoção de um novo nome nacional - ucranianos -, que finalmente prevaleceu. (RUDNYTSKYJ, I. Essays in modern ukrainian history. Edmonton: Printing Services. University of Alberta, 1987, p. 315)

${ }^{7}$ HIMKA, J. Galician villagers and the ukrainian national movement in the nineteenth century. Edmonton: Canadian Institute of Ukrainian Studies, 1988, p. xxiii.

${ }^{8}$ Esses são os versos iniciais de "Moisés", de Iwán Frankó, em que o poeta "se identifica com o vate judeu, vendo na história bíblica uma parábola da história de seu próprio povo". (KOLODY, H; SELANSKI, W. Moisés. Curitiba: Sociedade dos Amigos da Cultura Ucraniana, 1981, p. 14)
} 
integra o grupo de intelectuais do Leste Europeu que, especialmente após a segunda metade do século XIX, questionou os fundamentos das relações sociais da região. Para entender um pouco do programa desses populistas, vale recuperar as considerações de Isahia Berlin acerca desse movimento na Rússia. Ele esclarece que sob a insígnia "populistas" não se encontra um partido politico ou um conjunto coeso de doutrinas, mas sim um amplo movimento radical liderado por homens de origens e capacidades diferentes que dirigiam pequenos grupos independentes de conspiradores ou simpatizantes. Em comum, apenas compartilhavam os ideais democráticos dos radicais europeus de sua época, bem como a crença de que a luta entre as classes econômicas e sociais era o fator determinante na política. Como se sabe, a teoria da luta de classes surgiu no decorrer da Revolução Industrial no Ocidente e, naquele contexto, a ideia da coerção exercida pelos "possuidores" sobre os "despossuídos" alçou o proletariado à condição de classe revolucionária. Porém, a precária industrialização nos impérios russo e austro-húngaro fazia com que seus contingentes de operários fossem insignificantes, não passando de $2 \%$ a $3 \%$ da população total. ${ }^{9}$ Por isso, ali o populismo canalizou suas atenções para o campesinato, que "passou a ser entendido como o verdadeiro sal da terra". ${ }^{10}$ Os integrantes desse segmento, estrato mais baixo da população, eram representados "como mártires, cujos agravos estavam decididos a vingar e remediar, e como encarnações da virtude simples e incorrupta". ${ }^{11}$

As derrotas dos movimentos liberais no Ocidente em 1848-49, conforme Isahia Berlin, confirmaram aos populistas rutenos a convicção de que a correção das injustiças sociais se daria por meio de políticas de promoção social. Para eles, o que a vasta maioria dos camponeses e trabalhadores da Europa precisava era que lhes proporcionassem alimentos

\footnotetext{
${ }^{9}$ BERLIN, Isahia. Os pensadores russos. São Paulo: Companhia das Letras, 1988 , p. 214

${ }^{10}$ NARKIEWICZ, Olga. The green flag: Polish populists politics (1867-1970). London: Redwood Burn Ltda, 1976, p. 277.

${ }^{11}$ BERLIN, op.cit, p. 215.
} 
e roupas, segurança fisica e que a salvassem da doença, da ignorância, da miséria, da pobreza e das desigualdades humilhantes. ${ }^{12}$ Não obstante, diferentemente do que querem alguns intérpretes, o foco no campesinato não marca esse movimento como tradicional, pois o populismo desejava sim mudanças na sociedade. ${ }^{13}$

Com essa feição, o populismo se desenvolvia entre os rutenos, implementando ações sob a crença de que a emancipação da sociedade rural era condição necessária para a concretização de um Estado nacional. Além disso, como em outros movimentos protonacionais do século XIX, nesse, também o mundo camponês era representado como o mantenedor do que se mitificava como ethos nacional: ele seria o guardião das canções, das histórias e dos costumes populares, bem como da língua vernácula.

Ao estudar o populismo na província da Galícia, Olga Narkiewicz propôs que ele teria se manifestado por meio de três grandes correntes: a laica (socialista e não socialista), a clerical, com elementos cristãos, e a econômica, com fortes ingredientes de nacionalismo. ${ }^{14}$ Já entre os estudos que focalizaram apenas a Galícia Oriental, área ocupada majoritariamente pelos ucranianos, essas correntes não são destacadas, em que pese os pesquisadores assentirem quanto ao caráter nacionalista e clerical de seus populistas. Porém, esses estudos convergem quanto a localizarem na Galicia Oriental as manifestações e os resultados mais intensos do nacionalismo ruteno. À primeira vista, esse fato pareceria improvável, já que apenas $15 \%$ da população ucraniana vivia sob os domínio dos Habsburgos, estando a maioria restante sob o jugo dos czares. No entanto, como esclarece Magocsi, a maior liberdade do ambiente político no império austriaco teria favorecido a disseminação de ações populistas e nacionalistas mais intensas justamente na área da Galícia Oriental. $^{15}$

12 BERLIN, op. cit., p. 216

${ }^{13}$ NARKIEWICZ, op. cit, p. 273.

${ }^{14}$ Ibidem, p. 282.

${ }^{15}$ MAGOCSI, Paul. The roots of Ukrainian nationalism: Galicia as Ukraines's Piedmont. Toronto: University of Toronto Press, 2002, p. 119. 
Todavia, o esforço emancipatório dos populistas esbarrava na ignorância do campesinato. Com efeito, houve, na primeira metade do século XIX, por parte da Coroa austro-húngara, uma clara política de desestimulação do ensino para as camadas populares nas regiões da Galícia. É significativo que, em 1842, somente $15 \%$ das crianças galicianas frequentassem a escola, enquanto em outras regiões do Império, como na Boêmia, verificava-se uma frequência de 94\%; em toda a Áustria (com exceção da Galícia) esse índice era de $75 \%$. O quadro pouco se alterara nos finais da década de 1860, quando o governo austríaco passou a incentivar a educação em todas as regiões do Império, pois, na Galícia, sob a hegemonia da nobreza polonesa, essa medida não foi integralmente implementada. A situação refletiu um quadro desolador para a região: em 1880 , somente $17,3 \%$ dos homens e 10,3\% das mulheres conseguiam ler e escrever. Isso destoava do total do Império, onde as percentagens eram $61,9 \%$ e $55,1 \%$, respectivamente, de homens e mulheres alfabetizados. ${ }^{16}$ Mas foi no interior desse quadro de analfabetismo que a Coroa austríaca, desde meados do século XIX, permitiu a proliferação de escolas, jornais e de associações de caráter diverso, engendrando a possibilidade de uma verdadeira "revolução cultural" na região. ${ }^{17}$

Essa revolução ocorria, como vem sendo exposto, muito em decorrência da propagação, desde a segunda metade do século XIX, de organizações populistas, por meio das quais a elite educada - a intelligentsia - se dedicava a transmitir consciência cultural e nacional ao campesinato. Seus líderes ocupavam universidades, casas editoriais e academias como, por exemplo, a Sociedade Schevchenko. ${ }^{18}$ No entanto, para pesquisadores como Himka e Magocsi, as organizações mais influentes eram as que atuavam diretamente nas aldeias, causando impacto na vida cotidiana dos camponeses.

\footnotetext{
${ }^{16}$ HIMKA, J. op. cit, p. 15-16; ANDREAZZA, Maria Luiza. Paraíso das delicias: um estudo da imigração ucraniana para o Brasil. 1895-1995. Curitiba: Aos Quatro Ventos, 1998.

${ }^{17}$ HIMKA, J., op. cit, p. 56.

${ }^{18}$ MAGOCSI, op. cit., p. 119 ; HIMKA, J., op. cit, p. 60.
} 
Dentre essas, duas se destacaram: a Sociedade Kachkovs'kyi e a Sociedade Prosvita. ${ }^{19}$ Aqui, serão destacadas apenas as características da Prosvita dadas as evidencias recolhidas em outros estudos de que suas propostas tiveram ecos junto a imigrantes estabelecidos no Brasil. ${ }^{20}$

Essa associação foi fundada em 1868 por Stephen Kachala e diversos outros ativistas, como Anatoly Vachnhanyn e Omelian Partytzky. Suas intenções junto às populações rurais eram semelhantes às dos demais populistas e, assim, não parece ser por acaso que a tradução de Prosvita signifique iluminação. Originalmente um movimento cultural e educacional, a Prosvita ganhou força política com o apoio da juventude, principalmente aquela formada por estudantes de teologia. ${ }^{21} \mathrm{O}$ objetivo inicial, que tinha uma característica mais acadêmica e literária, passou a ser assumido pela Sociedade Schevtchenko a partir de 1870, enquanto a Prosvita foi se tornando um dos pontos centrais da consciência nacional ucraniana, dirigindo suas atividades fundamentalmente para a promoção da educação entre as massas camponesas.

Uma de suas mais importantes derivações foram os clubes ou salas de leitura. Esses clubes - tchetálhnia - eram instituições que buscavam criar um ambiente crítico com vistas a complementar a educação recebida nas escolas. No entanto, no mais das vezes, essas salas serviam para a própria alfabetização dos camponeses. O número de membros dos clubes de leitura espalhados pelas diversas aldeias era variado, apresentando grupos em torno de 50 a até mais de 100 sócios. Em meados da década de 1880 havia 400 salas e em 1906 já eram aproximadamente três mil, ${ }^{22}$ somando as promovidas pelas duas sociedades mais expressivas na região:

\footnotetext{
${ }^{19}$ MAGOCSI, op. cit., p. 120

${ }^{20}$ ANDREAZZA, M. L., op. cit.

${ }^{21}$ TERLETSKY, I. H. Educational and cultural movement in Galícia. In: UKRAINE: A CONCISE ENCYCLOPAEDIA. V. 2. Toronto: University of Toronto Press, 1971, p. 336.

${ }^{22}$ HIMKA, J., op. cit., p. 90
} 
Tabela 1 - Membros das principais associações populistas

\begin{tabular}{l|c|c}
\hline & KACHKOVS'KYI & PROSVITA \\
\hline Total de membros $(*)$ & 19.710 & 20.085 \\
\hline Membros em 1906 & 9.229 & 10.000 \\
\hline Salas de leitura & 1.261 & 1.693 \\
\hline
\end{tabular}

Fonte: MAGOCSI, Paul. The roots of ukrainian nationalism: Galicia as Ukraine's Piedmont, p. 136

Nota: (*) considerando os associados desde a criação dessas associações.

Destaca-se no movimento Prosvita a participação ativa de parte do clero greco-católico, especialmente a sua ala progressista, da qual era integrante o próprio Stephan Kachala. Muito em função disso ocorreu uma reestruturação do relacionamento entre os religiosos da ala progressista com a população rural, que deixou de enxergá-los apenas como ministradores de bens de salvação. ${ }^{23}$ Por isso, foi nesse contexto que a prática religiosa sob o rito grego passou a compor traço distintivo da etnicidade ucraniana; levando-se em conta que, em correspondência aos vários desdobramentos do cristianismo, a população da Galícia professava sua fé sob os ritos ortodoxo, grego (uniatas) e latino e que, conforme já foi observado por Hobsbawm,

[...] as verdades universais estão frequentemente em competição, e as pessoas que estão na fronteira de algumas dessas verdades podem, às vezes escolher outras como um distintivo étnico, como o fazem russos, ucranianos e poloneses para se diferenciarem entre si como católicos romanos, ortodoxos e uniatas. ${ }^{24}$

${ }^{23}$ Especificamente sobre as relações entre o clero, nacionalismo e populismo na Galicia, cf. HIMKA, John-Paul. Religion and nationality in Western Ukraine: the Greek Catholic Church and Ruthenian National Movement in Galicia. 18671900. Montreal: McGill-Queen's University Press, 1999.

${ }^{24}$ HOBSBAWM, E. J. Nações e nacionalismos desde 1870: Programa, mito e realidade. Rio de Janeiro: Paz e Terra, 1990, p. 83 
Kachala, em finais dos anos 1860, com discurso investido de autoridade clerical e populista, formulou peculiar teoria acerca da pobreza da população rural. Tanto as contradições sociais decorrentes da monetarização da economia quanto a ausência de industrialização que pudesse absorver o excedente da mão de obra da área rural eram usadas como justificativas pela grande maioria dos analistas laicos para a penúria regional, devido aos termos desiguais em que se deu a emancipação da servidão de gleba. Diferentemente, o reverendo Kachala responsabilizava o campesinato por sua situação, já que situava as raízes de sua miséria em seus próprios vícios: a embriaguez, o desperdício e a preguiça. ${ }^{25}$ Com base nisso, partiu do clero a formulação de uma ideologia que concebia o movimento nacional como uma luta dicotômica: da virtude contra o vício, da iluminação contra a ignorância, da sobriedade contra a embriaguez, da diligência contra a indolência e da frugalidade contra a prodigalidade. ${ }^{26}$ Estavam assentadas as bases para uma nova ética social que envolveu boa parte dos aldeões que a entendiam como mais um ponto a ser conquistado na construção de uma nova ordem social. Para tal, as paróquias, além das salas de leitura, passaram a implementar irmandades de temperança, escolas e cooperativas agrícolas.

O envolvimento da Prosvita com a criação de cooperativas agrícolas tem relação direta com as condições ambíguas daquela sociedade que se encontrava em pleno processo de transição, mas na qual as antigas estruturas de relações socioeconômicas insistiam em vigorar. De maneira geral, por exemplo, após 1848 , os nobres passaram a exigir pagamento em trabalho ou em dinheiro para que o camponês utilizasse as terras que haviam sido comunitárias. No entanto, muitos deles não reconheciam os novos direitos dos proprietários rurais e usavam ilegalmente as terras rústicas

\footnotetext{
${ }^{25}$ HIMKA, John-Paul. Voluntary artisans associations and the Ukrainian national movement in Galicia (the 1870s). In: MARKOVITS, Andrei; SYSYN, Frank E. (edit.) Nationbuilding and the politics of nacionalism. Harvard University Press, 1982, p. 192.

${ }^{26}$ HIMKA, J. op. cit., 1988, p. 125.
} 
e os pastos. ${ }^{27}$ Em função do impasse, a administração provincial passou a instalar comissões de direitos servis para examinar as demandas dos camponeses, as quais tendiam a favorecer os senhores das terras. Para que tenhamos uma noção das dimensões dessa questão, entre 1850 e 1900 as apelações relativas à querela sobre os direitos "servis" apareceram em 984 aldeias galicianas: dessas, 90\% localizavam-se na Galícia Oriental. ${ }^{28}$ Dada a ignorância do campesinato para formular por escrito as denúncias, esse contexto gerou uma figura social especifica: a dos individuos que possuíam educação formal e ganhavam suas vidas escrevendo as denúncias e petições dos camponeses. ${ }^{29}$

Apesar das vitórias das forças sociais conservadoras, conforme John-Paul Himka, a segunda metade do século XIX foi marcada pelo conflito entre serfdom and servitudes. ${ }^{30}$ Essa tensão traduzia-se, inicialmente, como foi descrito acima, nas estratégias desenvolvidas pela nobreza no sentido de continuar recebendo dos camponeses o tributo da corveia e, de outro, nas dos camponeses rutenos de manter os direitos tradicionais da exploração familiar e comunal da terra. Um bom exemplo disso se encontra na exigência de que os camponeses indenizassem os nobres pelos prejuizos causados com sua emancipação. Foi decidido pelo Parlamento que eles deveriam pagar tal compensação até 1898, por meio de impostos adicionais, cuja arrecadação permitiria indenizar a nobreza pela significativa perda da mão de obra servil. ${ }^{31}$

Foi nesse contexto de desagregação feudal que a Prosvita se envolveu em questões econômicas e passou a organizar armazéns comunitários, cooperativas comerciais e bancos de poupança e empréstimo. Também foram criados granários coletivos, pois, em função da escassez de grãos nos

\footnotetext{
${ }^{27}$ HIMKA, J. op. cit., 1988, p. 49.

${ }^{28}$ Ibidem.

${ }^{29}$ Ibidem, p. 17

${ }^{30}$ As palavras "serfdom" e "servitudes" podem ser traduzidas como "obrigações servis" e "direitos servis", respectivamente. (Ibidem, p. 1-48).

${ }^{31}$ Pode ser lembrado que os imigrantes em estudo chegaram ao Brasil em 1895. (HIMKA, J. op. cit., 1988, p. 29)
} 
períodos que antecediam o plantio, os camponeses necessitavam recorrer aos empréstimos dos usurários para a compra das sementes. Somente nas últimas décadas do século XIX foram desenvolvidas instituições bancárias modernas que acabaram com o empréstimo particular, especialmente difundido nas vilas da Galícia. Mesmo assim, em 1912, a Prosvita contava com 257 uniões de crédito. ${ }^{32}$

É preciso ressaltar que, como é característico a fases de intensas transformações estruturais, não existia uma sincronia no impeto das mudanças pretendidas pelos populistas. Cada região e, mais especificamente, cada aldeia experimentava a modernização em ritmo específico em função da temporalidade própria de cada um dos agentes modernizantes e das contradições sociais decorrentes. Assim, em finais do século XIX os elementos da cultura popular tradicional eram práticas vivas e significativas em boa parte dos campos da Galícia. O arraigamento das formas culturais pode ser associado tanto à ruralidade da vida social quanto à tolerância do clero conservador da Igreja de rito grego. Um exemplo disso aparece com clareza na comemoração da Páscoa - a mais importante festa da Igreja Oriental - cuja celebração até hoje atualiza signos pré-cristãos. Nessas condições, a religiosidade dos camponeses passou a ser objeto de preocupação da intelligentsia Prosvita. Para ela, as crenças e as práticas mágicas passaram a ser objeto de anátema por entrarem em conflito com a difusão de uma cultura racionalista entre os camponeses. Evidentemente, essa questão promovia desacordos no interior do clero, à medida que a facção progressista não concordava com a manutenção do magismo cristão efetuada pela ala tradicional da Igreja.

Assim, as atividades paroquiais da Prosvita expressavam as contradições dessa sociedade. Nessa linha, cabe acrescentar que não foi todo o campesinato que aderiu aos clubes de leitura, por exemplo. Houve resistências que podem ser atribuídas tanto ao conflito com a tradição oral, quanto ao medo de represálias por parte da nobreza. Em

32 TERLETSKY, op. cit., p. 336; HIMKA, J., 1988, op cit., p. 165. 
relação ao primeiro motivo, é exemplar a observação de um clérigo rural que, tendo fundado inúmeros clubes de leitura, tinha experiência com essa resistência:

[...] não existem razões de se ficar surpreso com os nossos aldeões. Sendo pouco esclarecidos, não entendem os benefícios dos clubes de leitura para sua instrução e, sendo conservadores, encontram dificuldades de se acostumar com alguma coisa que não esteja na aldeia desde há muito tempo. ${ }^{33}$

A oposição a essa prática estaria ligada à herança de uma mentalidade servil na qual a educação seria um atributo distintivo, característico de uma classe opressora e estrangeira. Isso está bem expresso nas palavras de um oponente ao clube de leitura na aldeia de Perviatychi, em 1884: "Serei um senhor para poder ler um jornal?". ${ }^{34}$

Já um segundo motivo contra os clubes de leitura seria pelo fato de grande parte da população acreditar que as iniciativas para melhorar a condição das camadas populares seriam reprimidas pelas autoridades. Esses temores tinham certo fundamento, uma vez que até os finais dos Oitocentos mantinha-se a censura aos jornais e textos e eram aprisionados os que difundiam literatura subversiva. A população tradicional, no entanto, associava as prisões dos radicais ao fato de "estarem lendo" e não à espécie de leitura que era efetuada.

Contudo, apesar dos inevitáveis segmentos refratários, as ações da Prosvita, notadamente os clubes de leitura, passaram a integrar a paisagem rural, com a adesão dos segmentos mais jovens da sociedade, basicamente homens. Reunidos nas escolas, salões paroquiais ou mesmo ao ar livre, liam, escutavam e debatiam o valor da Educação para a construção de uma sociedade mais justa e igualitária. Nessas conversas também descortinavam para si a possibilidade de refazer suas vidas além-mar. Particularmente a partir da década de 1890, seriam os que integrariam as levas de imigrantes que se dirigiram para a América. Dentre eles estava o

\footnotetext{
${ }^{33}$ HIMKA, J., op. cit., 1988, p. 86.

${ }^{34}$ Ibidem, p. 94. 
grupo que foi estabelecido na colônia rural Antonio Olyntho, o qual, como dito anteriormente, é objeto desse estudo.

No fim de tal destino já acampamos. Vivemos na floresta em cabanas e imensamente estamos trabalhando. Cortamos troncos grossos de braçada, com dois-três dias de espicaçada. Num ano vamos ter um descampado prá semear. Vivemos do fiado pois o governo por enquanto fia até obtermos sal, batata e milho.

Carta de Olexia - I. Frankó

As diretrizes brasileiras para a instalação de núcleos coloniais no Sul do Brasil preconizavam a pluralidade étnica, envolvendo no mesmo estabelecimento uma mescla de estrangeiros com nacionais. No entanto, quando em 1895 mais de dois mil ucranianos foram direcionados para a colônia Antonio Olyntho, eles passaram a conviver com número significativo de poloneses e alguns poucos italianos, alemães e brasileiros. Tal fato permite afirmar que, a despeito do projeto multiétnico, ela foi uma colônia de ucranianos e polacos. ${ }^{35}$

Porém, seria descabido supor que desde os primeiros momentos houvesse coesão étnica entre os próprios ucranianos, pois os integrantes das 350 famílias pioneiras emigraram de várias regiões da Galícia e, assim, portavam culturas diferenciadas. Como já foi visto anteriormente, aquela região era palco de uma enorme reestruturação que se processava em diversos graus - tanto na implementação quanto na aceitação. Ali conviviam camponeses integrados ao ideário populista - e portanto conscientes do poder da ação crítica e coletiva - com camponeses que viviam segundo formas ancestrais.

${ }^{35}$ ANDREAZZA, op. cit., p. 137. 
É pertinente considerar que, apesar das variações culturais entre os pioneiros, o idioma comum agia para facilitar a conversação entre eles. A língua, como já observou Barth, é recurso simbólico que permite marcar uma oposição significativa entre "nós" e "eles", pois "está lá desde sempre" e, portanto, é disponivel a todos os atores. ${ }^{36}$ Tendo em vista a inexistência de obstáculos linguísticos para a comunicação entre os imigrantes, é provável que uma situação ocorrida nos primórdios da colônia tenha inaugurado o movimento de integração do grupo. Ao mesmo tempo, e por esse mesmo motivo, pode ser considerado momento fundador da recriação étnica na localidade.

Esse momento se refere a uma insurreição ocorrida nos primeiros meses de 1896 e que colocou em forte antagonismo os estrangeiros e as autoridades brasileiras. O conflito adquire destaque, pois seu andamento detém fortes traços da racionalidade Prosvita, em particular no que tange à ênfase desse movimento em difundir o princípio de que os homens não deveriam se curvar ao arbitrio das autoridades, fossem elas laicas ou religiosas. Deveriam, sim, exigir os direitos assegurados em contratos e nas normas legais.

O conflito em questão pode ser associado à morosidade do processo de distribuição dos lotes que caberiam a cada família nas linhas vicinais da colônia. Os imigrantes se viam - e estavam - literalmente largados à própria sorte, não tendo a quem recorrer. Não possuíam representação oficial, já que o vice-consulado da Áustria-Hungria só foi estabelecido em Curitiba, capital do estado do Paraná, em setembro de $1896 .{ }^{37} \mathrm{~A}$ tensão deveria agravar-se pela dificuldade de comunicação com as autoridades brasileiras, posto que os imigrantes não dominavam o português. Ainda, não é descabido supor que estivessem com medo dos indios, haja vista que uma colônia de galicianos nas proximidades fora recentemente atacada por indios "botocudos". ${ }^{38}$ Portanto, e

\footnotetext{
${ }^{36}$ BARTH, F. op. cit., p. 164.

${ }^{37}$ Até então, havia vice-consulado apenas no Rio de Janeiro.

38 O que está sendo mencionado consta do relatório apresentado ao Dr. José Pereira Santos Andrade pelo bacharel Antonio Augusto de Carvalho Chaves, Secretário de Negócios, Justiça e Instrucção Pública, 1897 (DEAP).
}

24 Revista de História Regional 16(1): 9-36, Verão, 2011 
tendo em vista que se sugere neste artigo que esse conflito tenha servido como fundamento do processo de etnização, vale considerar os efeitos da adversidade na constituição dos sentimentos de solidariedade e coesão social.

Insatisfeitos com as condições em que estavam, Gregório Prokopiw, Theodoro Dzurelo, José Okunski, Wasílio Komar, Stanislau Szymanski e Casimiro Ozuch lideraram um motim ao qual se integraram os demais colonos. ${ }^{39}$ Segundo a argumentação oficial, eles se rebelaram contra o diretor da colônia apenas porque foram informados que não receberiam mais os alimentos que o estado lhes destinava enquanto não estivessem instalados em seus terrenos. ${ }^{40}$ Merece ser destacado que diversos relatórios oficiais do Paraná oitocentista abordam os frequentes problemas das autoridades paranaenses para instalar os imigrantes. Neles fica claro que aceitação dos fluxos migratórios não implicou prévia preparação de lotes coloniais, nos quais os imigrantes, tão logo chegassem ao Paraná, pudessem ativar uma plantação para sua subsistência. Podem-se somar a isso problemas como a incompetência dos topógrafos contratados pela Inspetoria de Colonização e querelas em torno da posse das terras devolutas nas quais o estado estava instalando o núcleo colonial.

O motim assumiu tal proporção que foi necessário que as autoridades enviassem reforços policiais, deslocando pelotões das redondezas para acalmar a situação no núcleo colonial. A fúria dos colonos tinha razão de ser, pois sete meses após o desembarque dos imigrantes, esses ainda estavam lotados em barracões coletivos. O convivio compulsório com pessoas que até então lhes tinham sido totalmente estranhas e a informação de que não receberiam mais alimentação do governo constituíram estopim suficiente para deflagrar o levante. No entanto, é legitimo pensar que eles

\footnotetext{
${ }^{39}$ Todos os indivíduos citados como líderes da rebelião são rutenos/ucranianos. Seus nomes foram colhidos no relatório apresentado ao Dr. José Pereira Santos Andrade, governador do estado do Paraná, pelo bacharel Antonio Augusto de Carvalho Chaves, Secretário de Negócios do Interior, Justiça e Instrucção Pública em $1^{\circ}$ de setembro de 1896. Curityba: Typ. Modello a Vapor, 1896, p. 5 (DEAP).

${ }^{40}$ Ibidem, p. 5.
} 
não se insurgiram apenas pelo fato de não receberem mais a alimentação; que o conflito não foi "espasmódico", consistindo "mera intromissão de gente comum na cena histórica ocasionando repentina perturbação social". ${ }^{41}$ Ao contrário, há indicadores suficientes para evidenciar que os imigrantes se revoltaram por lhes ser negada a oportunidade de retomar suas vidas. Nessa linha, cabe indicar que mesmo tendo-se evadido do local, conforme consta no relatório policial, os líderes retornaram a Antonio Olyntho assim que se acalmou a situação. Todos eles receberam seus lotes na linha Candido de Abreu, que foi demarcada depois de setembro de 1896 e, em sua grande maioria, mantiveram-se na localidade até morrer. Esse foi o caso, por exemplo, de José Okunski, cujo obituário em 1928 diz o seguinte: "Com a avançada idade de 73 anos faleceu no dia 4 do corrente o prestante colono José Okunski, homem probo e trabalhador". ${ }^{42}$

Certamente esse "motim Prosvita" serviu para definir lideranças e iniciar a coesão social de pessoas egressas de diferentes aldeias da Galícia e que ali conviviam tão somente pelo fato migratório. Entre eles, portanto, era urgente selecionar, adaptar e mobilizar artefatos culturais que agissem como marcadores de pertença étnica bem como, e sobretudo, conferindo sentido às ações e relações na e da comunidade. Essa dinâmica, como será visto a seguir, também foi marcada pelos ideais Prosvita.

No processo de recriação étnica foi expressivo o arraigamento dos imigrantes à profissão da fé sob o rito grego. Nessa particularidade, cabe observar que nos primeiros 15 anos da colônia apenas esporadicamente ela foi atendida por religiosos do rito grego. Em carta enviada à Galícia, em 1922, os pioneiros mencionam o abandono religioso que vivenciaram por muito tempo. Segundo eles, o responsável por administrar a paróquia, o reverendo Clemente Bjuh'ovskei, os visitava apenas duas a três vezes por ano. ${ }^{43}$

${ }^{41}$ THOMPSON, Edward P. Economia moral da multidão. In: THOMPSON, Edward

P. Costumes em comum. São Paulo: Companhia das Letras, 1998, p. 150.

42 GAZETA DO POVO. Noticias do Estado - Antonio Olyntho. Curitiba, n. 2.984, p. 8, 15 jul. 1928.

${ }^{43}$ CORRESPONDÊNCIA DOS IMIGRANTES, 1922. n.p. Arquivo Provincial da Ordem Basiliana. Prudentópolis. (Tradução livre). 
Havia a opção de frequentar o culto religioso na igreja de rito latino. Possivelmente animados pelo nacionalismo do espírito Prosvita, um grupo de pioneiros reagiu a essa possibilidade e, por volta de 1904, abandonou "a capela até então comum transferindo-se para um prédio adquirido para este fim, adaptando a casa ali existente para uma capela provisória". ${ }^{44}$ Isso é muito significativo na argumentação de que a tradição religiosa, em grande medida associada ao Prosvita, teve peso na fixação das fronteiras étnicas da localidade. Se a autodemarcação dos ucranianos fosse alheia à questão religiosa, os pioneiros poderiam, por exemplo, manter-se na posse da igreja "latina": afinal eram em maior número. Os dados a esse respeito indicam que ali havia, em 1896, 70 famílias polonesas e 350 ucranianas. Então, sendo maioria na colônia, por que os ucranianos não ficaram com a igreja existente? Possivelmente, pelas especificidades de sua religião. A tradição oriental possui simbologia própria, não apenas na conformação da liturgia e no calendário como também na estrutura arquitetônica e nos elementos decorativos próprios a seus templos.

Nessa fase de autodemarcação, tudo indica que os colonos sentiram necessidade de colocar em ação os princípios da Sociedade Prosvita. Não apenas Antonio Olyntho, como as demais colônias ucranianas do Paraná foram tomadas por uma verdadeira ânsia de escolaridade, ${ }^{45}$ associando muito intimamente o sucesso da imigração com o princípio da educação. As escolas e as salas de leitura nas sociedades Prosvita faziam parte do projeto dos ucranianos no Brasil durante a década de 1900, e os colonos de Antonio Olyntho não se furtaram a essas intenções. A esse respeito relataram ao Metropolita Andrei Szeptetzkei:

[...] ao lado da igreja construímos uma casa para a moradia do sacerdote quando nos visitava e onde as crianças pudessem reunir-se para receber os ensinamentos escolares. Além

${ }^{44}$ Livro Tombo do Curato Antonio Olintho. Manuscrito. Arquivo da Paróquia de Nossa Senhora da Conceiçao. Antonio Olinto. p. 2.

45 BORUSZENKO. A imigração ucraniana. In: WIRTSCHAFTSKRÄFTE UND WIRTSCHAFTSWEGE. Klett-Cotta: München, 1981, p. 760-761. 
disso, compramos uma chácara e destinamos os lucros para as despesas comunitárias como igreja, escola, clube de leitura e outras. Todos estes bens eram administrados por nós mesmos, através de um comitê eleito, e com a participação do padre Bjuh'ovskei. ${ }^{46}$

Nos esforços para prover a educação de crianças e adultos, as iniciativas individuais eram louvadas: o empenho de Stephan Duma, por exemplo, foi citado até no Boletim Colonial e Agrícola, que tinha grande divulgação entre os imigrantes de todo o estado do Paraná. Estabelecido em Antonio Olyntho, esse imigrante ministrava suas aulas possuindo apenas uma cartilha: durante a noite, ele repassava para os papéis tudo aquilo que iria lecionar, em número equivalente ao de alunos que tinha na sala, para no dia seguinte entregar às crianças. ${ }^{47}$

Deve ser enfatizado que toda essa organização, apesar de desenvolver suas atividades no âmbito paroquial, era essencialmente um movimento leigo. Nessa época, como já foi destacado, os religiosos que atendiam a capela local o faziam de forma itinerante. Assim, os imigrantes mantiveram sua célula Prosvita em torno de uma igreja, mas não pela ação direta do clero. E, passados 15 anos da instalação na colônia, sentiam-se suficientemente organizados para aspirar um guia espiritual fixo. Assim, em 24 de agosto de 1911, chegou a Antonio Olyntho o padre secular João Michalczuk que, para o bem e para o mal, ali ficou até 1950, ano em morreu.

\footnotetext{
${ }^{46}$ CORRESPONDÊNCIA DOS IMIGRANTES, 1922. n.p. Arquivo Provincial da Ordem Basiliana. Prudentópolis. (Tradução livre).

47 KWASSINSKI, T. In: BOLETIM COLONIAL E AGRICOLA DO ESTADO DO PARANÁ. Curitiba, 1907-1908, p. 264.
} 
O portador do carisma assume tarefas que considera adequadas e exige adesão em virtude da sua missão.

Max Weber

O novo pároco encontrou os ucranianos organizados tanto como paróquia - coesos sob um signo da fé - quanto associados em torno de ideais de nacionalidade, educação e cooperação - a Sociedade Prosvita. E, sobretudo, dispostos a ter um dirigente espiritual; como escreveram mais tarde, "a ter um pai" ${ }^{48}$ Haviam construído capelas para realizar o culto, edificaram residências para acolher o padre, escolas para alfabetizar adultos e crianças e buscavam a organização cooperativa. Não suspeitavam, porém, que a vinda desse clérigo lhes retiraria a liberdade de gerenciar suas próprias vidas. ${ }^{49}$

Ao chegar à colônia, o padre João Michalczuk sistematizou a vida religiosa dos fiéis, esforçando-se para agregar seus paroquianos a uma série de elos devocionais. Isso implicava interferir em seus cotidianos e, desde o inicio, Michalczuk sentiu-se autorizado a impor o comportamento que entendia como adequado. Iniciou com a disciplinarização das festas, interferindo principalmente na vida dos jovens. Outra frente na qual o padre se empenhou desde os primeiros tempos foi pela temperança da comunidade, fazendo o povo jurar que apenas beberia quando tivesse seu consentimento. ${ }^{50}$

As pessoas curvaram-se à tenacidade daquele que era o representante do sagrado. Desse rigor decorre uma associação imediata com sua passagem pelo exército, antes de ingressar na carreira clerical. Com um temperamento forte, Michalczuk sentia-se à vontade no papel de clérigo tradicional, não hesitando em agredir os paroquianos com um

\footnotetext{
${ }^{48}$ CORRESPONDÊNCIA DOS IMIGRANTES, 1922. n.p. Arquivo Provincial da Ordem Basiliana. Prudentópolis. (Tradução livre).

${ }^{49}$ Cf. ANDREAZZA, op. cit. 1998; particularmente o capítulo 3.

${ }^{50}$ Livro Tombo do Curato Antonio Olyntho, p. 34.
} 
chicotinho de couro do qual não se separava. ${ }^{51} \mathrm{E}$ mais, não dispensava a violência nas palavras ásperas que dirigia aos paroquianos, como nos relata uma carta que os próprios enviaram à Galícia, dizendo que, no seu sermão, Michalczuk não hesitava em esbravejar: "Vocês são ignorantes, não passam de lixo". ${ }^{52}$

Nas bases autoritárias em que o pároco estabelecia sua relação com os paroquianos, foi inevitável o desenvolvimento de uma relação de agudo antagonismo. Dentre os inúmeros conflitos pode ser destacada a questão da unificação das irmandades religiosas que congregavam os ucranianos de Antonio Olyntho. Nesse enfrentamento, os momentos mais ruidosos se deram entre 1916 e 1918. Tudo porque, quando o padre João chegou à localidade, os pioneiros já haviam criado duas irmandades: uma na sede da colônia e outra associando os moradores da linha vicinal de Santos Andrade e de seus arredores. Como já foi dito aqui, as associações paroquiais não se ocupavam apenas das questões espirituais. Sob a rubrica de Irmandade São João Batista e São Basílio eram implementadas as atividades de duas unidades do Prosvita local. Os imigrantes possivelmente as criaram espelhando-se nas experiências que tiveram em suas aldeias da Galícia, onde o clero progressista congregava as atividades próprias da Igreja com as da escola e da cooperativa agrícola.

O fato de Michalczuk, legítimo representante do clero tradicional, querer unificar as irmandades criava um impasse: quem assumiria os rumos do Prosvita local, até então dirigida por leigos? $\mathrm{O}$ pároco, naturalmente, exigiu o comando não apenas das questões religiosas como da posse dos bens das sociedades. Disso é prova, por exemplo, uma escritura registrada em 1916 que transferia os bens da igreja matriz para o padre João Michalczuk. A esse respeito devese notar que, sendo padre diocesano, Michalczuk poderia ter bens registrados em seu nome. Fatos como esses geraram um período de intenso conflito, culminando com ações judiciais,

${ }^{51}$ Depoimento de integrante da comunidade. (1994)

52 CORRESPONDÊNCIA DOS IMIGRANTES, 1922. n.p. Arquivo Provincial da Ordem Basiliana. Prudentópolis. (Tradução livre).

30 Revista de História Regional 16(1): 9-36, Verão, 2011 
movidas junto ao tribunal da Lapa, contra Michalczuk e a diretoria da "Sociedade Católica Rutena", acusando-os de defraudadores do dinheiro e do patrimônio da paróquia, derivado exclusivamente do esforço dos pioneiros. ${ }^{53}$

No entanto, a resistência da liderança laica à atuação de Michalczuk foi decrescendo na medida em que ele recebia apoio das instâncias superiores. A Mitra Diocesana, quando informada da irregularidade do comportamento do clérigo, aconselhava aos imigrantes que fossem bons filhos. ${ }^{54} \mathrm{Da}$ mesma forma, as autoridades civis procuradas pelos colonos dificilmente se arriscariam a contrariar uma autoridade eclesiástica. Prova disso são os resultados dos processos criminais movidos contra o padre. Deve-se acrescentar, ainda, que desde 1917, quando a colônia passou a pertencer ao município de Rio Negro, o padre João Michalczuk, além de ser membro do Diretório Político Municipal foi alçado ao cargo de chefe politico de todo o distrito. ${ }^{55}$ Acabaram-se aí, definitivamente, suas idas e vindas para os tribunais.

Perante tantos insucessos, os colonos perverteram os principios racionalistas da Prosvita tentando uma solução radical: matar o padre. As tentativas nesse sentido fazem parte da memória coletiva da comunidade e foram informadas, ainda em 1913, pelo próprio Michalczuk em carta que dirigiu ao Metropolita Andrei Szeptetzkei. ${ }^{56}$ Ao redigi-la afirmava saber das intenções de certos paroquianos que lhe eram hostis, mas que continuava vivo e forte.

O fato é que, gradativamente, a ascendência do clérigo sobre os colonos assumia contornos que, quando de sua chegada, seriam improváveis. Um indicativo disso é a narrativa de um jornalista ucraniano, Karmanskyj, que passou

\footnotetext{
${ }^{53}$ PARANÁ. FORUM DA CIDADE LAPA. Summario-Crime. Juízo de Direito da Comarca da Lapa. 08/01/1916. Requerente: Júlio Reva. Requeridos: Padre João Michalczuk, João Sambulski, Elias Wons, Nicolau Schner, Gregorio Wiçoski e Alfredo Schner. (Processo-crime não catalogado).

${ }^{54}$ Livro Tombo do Curato Antonio Olyntho, p. 18 .

${ }^{55}$ Idem, p. 21.

56 CORRESPONDÊNCIA DE IWAN MICHALCZUK, junho, 1913. Arquivo Metropolita Andrei Szeptetzkei. Lwiw.
} 
por Antonio Olyntho em 1922. Em suas palavras, Michalczuk reeditava a relação senhor e servo:

A casa do padre, imponente e muito bonita, esconde-se no meio de um lindo bosque. Cada canto é bem cultivado e bem limpo. No pomar estão algumas macieiras, algumas pereiras e uma raridade no Brasil: alguns carvalhos [...] Passeei olhando o resto das construções da propriedade. Admirei-me com a perseverança do proprietário, surpreendi-me com o modelo de ordem em tudo, e tive ciúmes: é um verdadeiro senhor no sentido exato da palavra. ${ }^{57}$

Efetivamente, inúmeras evidências parecem confirmar que, desde o início da década de 1920, o pároco assumiu enorme dominio sobre a vida de seus paroquianos. Para tanto, antes disso, ele precisou vencer seus opositores Prosvita nas batalhas jurídicas e, sobretudo, nos embates cotidianos, de fundo religioso, que favoreceram definir a legitimidade de seu controle social. Mais do que isso, ele acionou mecanismos coercitivos, de natureza religiosa e não religiosa, que praticamente obrigaram muitos de seus opositores a tentar a vida em outras localidades. Já se pôde demonstrar aqui que, dada a crescente hegemonia de Michalczuk no cenário local, a década de 1920 marcou uma reestruturação social da colônia. Nessa reestruturação, é significativo indicar que, desde então, as pessoas que se destacavam na liderança laica tenham desaparecido dos registros paroquiais. Mais do que mero fenômeno migratório, isso sugere que na localidade se mantiveram apenas os grupos arraigados a um comportamento camponês tradicional. A eles restou a retomada da tradicional submissão à autoridade do "senhor", "nobre" ou "clérigo".

\footnotetext{
${ }^{57}$ KARMANSKYJ, Petró. Miz ridneme u pivdeniy Améretzi. Kiev/Viena/Lwiw: Tcahika, n.d., p. 104.
} 
Após acompanhar o papel do ideário Prosvita nas tensões presentes na reestruturação social dos imigrantes de Antonio Olyntho, é possivel resgatar as observações que abrem este texto acerca das tendências da produção historiográfica dedicada aos imigrantes. Como dito anteriormente, ao abordar o imigrante-citadino é mais frequente que essa produção focalize a participação e a influência dos estrangeiros nos movimentos operários da Primeira República. Por outro lado, quando tematiza o imigrante-colono, o mais comum é que enfatize seu papel na disseminação e valorização do trabalho livre num país que, ao final dos Oitocentos, acabava de libertar seus escravos. Ainda, o mais comum é que a historiografia se dedique a mostrar a celeridade com que, na área rural, os colonos tiveram êxito em reorganizar sociabilidades pautadas em etnicidade.

Grosso modo, pode-se dizer que tais diferenças de abordagem encontram uma explicação na pluralidade dos tempos sociais do Brasil da Primeira República que geravam, simultaneamente, acontecimentos capitais diferenciados para os homens dos meios rural e urbano. Por isso, os historiadores que focalizam fenômenos ocorridos nas cidades brasileiras e que contaram com a participação das camadas populares tendem a destacar nesse cenário as tensões e contradições decorrentes da urbanização e da alteração radical nas relações de trabalho em função do início da industrialização do país. Como se sabe, as cidades, particularmente aquelas associadas à economia do café, foram escolhidas como local de estabelecimento de muitos estrangeiros que vieram ao Brasil sem a intenção de ganhar seu sustento na lida agrária. Dessa forma, esse contingente integrou o emergente operariado brasileiro e, por isso, teve papel ativo nas primeiras conquistas dos trabalhadores. Já a dinâmica do tempo social vivenciado pelos colonos, particularmente nos estabelecimentos rurais do Brasil Meridional, era de outra natureza. Ali, o tempo cíclico do mundo camponês pôde ser reeditado por longas 
décadas, já que parte significativa desses estabelecimentos logrou manter certo distanciamento para com a sociedade envolvente. Isso não significa, contudo, que os colonos nela radicados tenham vindo para o Brasil absolutamente alheios aos ideários dos inúmeros movimentos sociais e políticos que percorreram a Europa, provocando ali eventuais rearranjos nas relações econômicas, nas estruturas políticas e na conformação social (não por acaso, boa parte desse período se inclui na Era das Revoluções). Significa apenas que a ruralidade de suas vidas lhes impunha isolamento e dificuldades, fatores que, por si só, encaminham as demandas coletivas para outras searas. Pode-se dizer que foi exatamente isso que ocorreu em Antonio Olyntho, onde uma memória social sacralizada, a distância geográfica do movimento Prosvita, a pífia e ineficiente presença do Estado brasileiro para garantir mínimos direitos aos imigrantes e seus descendentes permitiram o desmantelamento dos propósitos populistas e favoreceram que os desmandos e abusos do padre Michalczuv se desdobrassem por quatro décadas.

Finalizando, vale mencionar que o acompanhamento das relações que esses colonos tiveram com seu pároco nos incita a pensar o quão próximos ainda vivemos daquele mundo mágico e obscurantista pretensamente abolido pela Razão em 1789, no Ocidente, e em 1848, no Leste Europeu. A multiplicidade de caminhos que os grupos sociais percorrem opondo dominação e submissão, razão e fé, saber e obscurantismo não podem ser desvendados se, analiticamente, mantivermos ativos o ingênuo axioma de que, em se tratando de formas binárias, o predomínio de uma dessas racionalidades implique, necessariamente, na exclusão da outra. Ademais, experiências coletivas como as acima analisadas demonstram a especial complexidade que assumem as relações sociais permeadas pela presença do sagrado.

Resumo: Contrariando a tendência historiográfica de associar consciência política aos imigrantes fixados nas cidades e consciência étnica aos radicados no meio rural, o presente estudo busca destacar os efeitos das campanhas de eman-

34 Revista de História Regional 16(1): 9-36, Verão, 2011 
cipação dos populistas do Leste Europeu nas ações de pioneiros em colônias rurais brasileiras. Para tanto, reconstrói as relações de um grupo de imigrantes ucranianos estabelecido no Brasil com o pároco que os assistiu entre 1911 e 1950. Homem autoritário, João Michalkzuck valeu-se de inúmeros recursos, em particular da ascendência espiritual, para assenhorear-se da localidade; suas investidas, por largo tempo, encontraram ampla resistência. Boa parte dos pioneiros estava imbuída do espírito Prosvita que animava o nacionalismo galiciano e, por isso, combatia o domínio do clero tradicional sobre o campesinato. Contudo, o peso de uma memória social sacralizada, a distância das lideranças Prosvita e a pífia presença do Estado brasileiro para garantir mínimos direitos aos integrantes dessa comunidade permitiram que os desmandos e abusos do padre João se desdobrassem por quatro décadas.

Palavras-chave: Imigração. Ucranianos. Prosvita. Populismo.

Abstract: Countering the historiographical tendency of linking political awareness to immigrants established in cities and ethnic consciousness to those rooted in the rural areas, this study aims to highlight the effects of the campaigns for emancipation of Eastern European populists in the actions of pioneers in the Brazilian rural settlements. To this end, it reconstructs the relations of a group of Ukrainian immigrants established in Brazil with the parish priest that attended them between 1911 and 1950. As an authoritarian man, João Michalkzuck used several resources, especially his spiritual ascendency, to dominate the region. However, his attempts faced a strong resistance for a long period of time. Much of the pioneers were imbued with the Prosvita spirit that animated the Galician nationalism and, therefore, fought the domain of the traditional clergy over the peasantry. Nevertheless, the weight of a sacralized social memory, the distance of the Prosvita leaderships from the region and 
the below par presence of the Brazilian state to guarantee the basic rights for the members of this community allowed the excesses and abuses of to unfold for four decades.

Keywords: Immigration. Ukrainians. Prosvita. Populism.

Artigo recebido para publicação em 21/03/2011

Artigo aprovado para publicação em 21/03/2011 